\title{
Cytokine status' pattern in acute period of ischemic stroke subtypes
}

\author{
S. I. Shkrobot, N. R. Sokhor, L. S. Milevska-Vovchuk, L. V. Shkrobot \\ State Institution of Higher Education “I. Horbachevskyy Ternopil State Medical University”, Ukraine
}

Purpose. The aim of this study was to assess a different pattern of inflammatory mediators in relation of ischemic stroke subtypes in acute period.

Materials and Methods. The study involved 482 patients with different ischemic stroke (IS) subtypes. We studied the content of inflammatory interleukins (IL-1 $\beta$, IL-2, IL-6, IL-8, CRP, TNF- $\alpha$ ) and anti-inflammatory interleukin IL-10 in blood serum.

Results. The study revealed increasing content of pro-inflammatory cytokines in acute period of IS subtypes, especially at Large Artery Atherosclerosis (LAAS) and Cardioembolic Infarct (CEI). In patients with LAAS the level of IL-2, IL-6 and CRP was significantly higher compared to other IS subtypes. The content of IL-10 was significantly lower compared to patients with Undetermined Etiology (UDE) stroke and LACunar (LAC) stroke. We established the relationship between the concentration of IL- $1 \beta$ and IL- 6 with the severity of LAAS, CEI and UDE on the $1^{\text {st }}$ day of stroke. On the $7^{\text {th }}$ day the concentration of IL-1 $\beta$ and IL- 8 was significantly decreased at LAC, IL-2 - at LAC and LAAS, IL- 6 and TNF- $\alpha$ at LAC and UDE. At LAAS the content of inflammatory mediators depended on the degree of arteries stenosis, the presence of unstable atherosclerotic plaques, the intima-media thickness. We found a direct relationship between the severity of LAAS and CEI on the $14^{\text {th }}$ day with the CRP concentration on the $1^{\text {st }}$ day (at LAAS $-(r=0.73, p=0.003)$, at CEI $-(r=0.71, p=0.002)$, indicating predictive value of CRP-content on the course of acute period of IS subtypes. We established the dependence between cardiac morphometric parameters with the level of pro-inflammatory interleukins in acute period of UDE. We found the relation between the content of IL-1 $\beta$, IL-6 with left ventricular myocardial mass index at UDE.

Conclusions. The content of inflammatory mediators in acute period of ischemic stroke depends on the pathogenic subtype of stroke.

\section{Зміни цитокінового статусу при різних підтипах ішемічного інсульту в гострому періоді}

\section{С. І. Шкробот, Н. Р. Сохор, А. С. Мілевська-Вовчук, А. В. Шкробот}

Мета роботи - оцінити особливості змін медіаторів запалення в гострому періоді різних підтипів ішемічного інсульту (II).

Матеріали та методи. Обстежили 482 особи, які хворі на різні підтипи II (125 - із кардіоемболічним (КЕІ), 119 - 3 атеротромботичним (ATI), 116 - з інсультом невизначеної етіології (IHE) та 122 - з лакунарним (ЛІ)). Хворим здійснили клініко-неврологічне обстеження, вивчена динаміка вмісту прозапальних цитокінів (IL-1 $\beta$, IL-2, IL-6, IL-8, CPП, ФНП- $\alpha$ ) та протизапального цитокіну IL-10 у сироватці крові.

Результати. Встановили, що в гострому періоді всіх підтипів II на 1 добу зростає вміст прозапальних цитокінів, зокрема найбільшою мірою при АTI та КЕІ. У хворих з АTI рівень ІЛ-2, ІЛ-6 і СРП був вірогідно вищим, ніж при інших підтипах II, а вміст IJ-10 - вірогідно нижчим порівняно з IHE та ЛІ. Встановлений зв'язок між концентрацією IL-1 $\beta$ та IL-6 із тяжкістю ATI, KEI та IHE на 1 добу захворювання. На 7 добу концентрація IL-1 $\beta$ та IL-8 вірогідно знижувалася при ЛI, IL-2 - при ЛI та ATI, IL-6 і ФHП- $\alpha$ - при ЛI та IHE. Концентрація IL-10 на 7 добу KEI та ATI знижувалась, що свідчило про утримання дисбалансу між прозапальними та протизапальними цитокінами при цих підтипах II. При ATI на вміст медіаторів запалення впливали ступінь стенозу артерій, наявність нестабільних атеросклеротичних бляшок, товщина комплексу інтима-медіа. Виявлена пряма залежність між тяжкістю ATI і KEI на 14 добу з концентрацією СРП на 1 добу (при ATI - ( $r=0,73, p=0,003)$, при KEI - $(r=0,71, p=0,002)$, що вказувало на прогностичне значення вмісту СРП для перебігу гострого періоду цих підтипів II. Встановлена залежність між морфометричними показниками серця з рівнем прозапальних інтерлейкінів у гострому періоді IHE. Виявлений зв'язок між вмістом IL-1ß, IL-6 та індексом маси міокарда лівого шлуночка при IHE.

Висновки. У гострому періоді ішемічного інсульту вміст медіаторів запалення залежить від патогенетичного підтипу інсульту.

\section{Изменения цитокинового статуса при разных подтипах ишемического инсульта в остром периоде}

С. И. Шкробот, Н. Р. Сохор, А. С. Милевская-Вовчук, А. В. Шкробот

Цель работы - оценить особенности изменений медиаторов воспаления в остром периоде различных подтипов ишемического инсульта (ИИ).

Материалы и методы. Обследовано 482 больных с разными подтипами ИИ (125 - с кардиоэмболическим (КЭИ), 119 - с атеротромботическим (АТИ), 116 - с инсультом неустановленной этиологии (ИНЭ) и 122 - с лакунарным (ЛИ)). Больным проведено клинико-неврологическое обследование, изучена динамика уровня провоспалительных цитокинов (IL-1 $\beta$, IL-2, IL-6, IL-8, CРП, ФНП- $)$ и противовоспалительного цитокина IL-10 в сыворотке крови.

Результаты. Установлено, что в остром периоде всех подтипов ИИ на 1 сутки возрастает содержание провоспалительных цитокинов, в частности, в наибольшей степени при АТИ и КЭИ. У больных с ATИ уровень IL-2, IL-6, CРП был достоверно выше, чем при других подтипах ИИ, а уровень IL-10 - достоверно ниже по сравнению с ИНЭ и ЛИ. Установлена связь 
между концентрацией IL-1 $\beta$ и IL-6 и тяжестью АТИ, КЭИ и ИНЭ на 1 сутки заболевания. На 7 сутки концентрация IL-1 $\beta$ и IL-8 достоверно снижалась при ЛИ, IL-2 - при ЛИ и ATИ, IL-6 и ФНП- - при ЛИ и ИНЭ. Уровень IL-10 на 7 сутки КЭИ и АТИ снижался, что свидетельствовало об удержании дисбаланса между провоспалительными и противовоспалительными цитокинами при этих подтипах ИИ. При АТИ на содержание медиаторов воспаления влияли степень стеноза артерий, наличие нестабильных атеросклеротических бляшек, толщина комплекса интима-медиа. Обнаружена прямая зависимость между тяжестью атеротромботического и кардиоэмболического инсультов на 14 сутки и концентрацией СРП на 1 сутки (соответственно при АТИ - $(r=0,73, p=0,003)$, при КЭИ - $(r=0,71, p=0,002)$, что свидетельствует о прогностическом значении содержания СРП на течение острого периода этих подтипов ИИ. Установлена зависимость между морфометрическими показателями сердца и уровнем провоспалительных интерлейкинов в остром периоде ИНЭ. Выявлена связь содержания IL-13, IL-6 с индексом массы миокарда левого желудочка при ИНЭ.

Выводы. В остром периоде ишемического инсульта содержание медиаторов воспаления зависит от патогенетического подтипа инсульта.

\section{Introduction}

Stroke is a frequent cause of long-term disability and death worldwide. Ischemic stroke is more commonly encountered compared to hemorrhagic stroke, and leads to tissue death by ischemia due to occlusion of a cerebral artery [1]. Recent work has shown that post stroke inflammation contributes significantly to the development of ischemic pathology [2]. The immune response to acute cerebral ischemia is a major factor in stroke pathobiology and outcome. While the immune response starts locally in occluded and hypoperfused vessels and the ischemic brain parenchyma, inflammatory mediators generated in situ propagate through the organism as a whole [3]. Works over the past few decades indicate that aspects of this inflammatory response may in fact be detrimental to stroke outcome. However, it is difficult to elucidate the precise mechanisms of the inflammatory responses following ischemic stroke because inflammation is a complex series of interactions between inflammatory cells and molecules, all of which could be either detrimental or beneficial.

The concept of ischemic stroke pathogenetic heterogeneity provides a variety of causes and mechanisms of acute focal brain damage. In this case, common stage at all ischemic stroke subtypes is only the final one of the destructive process, while their pathogenesis is different. Based on pathophysiologic differences of each stroke subtype it is possible to hypothesize a different pattern of immune inflammatory activation in relation of ischemic stroke subtype [4].

Variable cytokine status at ischemic stroke subtypes was studied in several works. In particular, low immuno-inflammatory profile of acute lacunar infarct (LAC) and the high immuno-inflammatory profile of Large Artery Atherosclerosis (LAAS) and particularly of cardioembolic infarct (CEI) were demonstrated [5]. Although other studies have shown that among recent LAC patients, IL-6 and TNF receptor concentrations predict risk of recurrent vascular events, and they are associated with the effect of antiplatelet therapies [6]. However, despite the large number of studies devoted to

Table 1. The distribution of ischemic strokes subtypes according to the severity of neurological deficit, abs., $\%$

\begin{tabular}{lllll}
\hline Stroke subtypes & \multicolumn{2}{l}{ Stroke severity } & & \\
\cline { 2 - 5 } & Minor & Moderate & $\begin{array}{l}\text { Moderatel } \\
\text { Severe }\end{array}$ & Severe \\
\hline CEI $(n=125)$ & $26(20.8 \%)$ & $52(41.6 \%)$ & $38(30.4 \%)$ & $9(7.2 \%)$ \\
LAAS $(n=119)$ & $27(22.7 \%)$ & $53(44.5 \%)$ & $35(29.4 \%)$ & $4(3.4 \%)$ \\
UDE $(n=116)$ & $40(34.5 \%)$ & $59(50.9 \%)$ & $13(11.2 \%)$ & $4(3.4 \%)$ \\
LAC $(n=122)$ & $45(36.9 \%)$ & $70(57.4 \%)$ & $7(5.7 \%)$ & - \\
\hline
\end{tabular}

this issue, the role of different factors affecting the pattern of cytokine status in acute period of ischemic stroke subtypes is not completely clarified.

\section{Purpose}

The aim of this study was to assess a different pattern of immuno-inflammatory activation in relation of ischemic stroke subtypes in acute period.

\section{Material and Methods}

Subjects for the present analysis (four hundreds and eighty two patients) were selected from an ongoing prospectively collected cohort of patients with ischemic stroke subtypes, admitted to the neurological departments in Ternopil Regional Communal Clinical Psychoneurological Hospital. Among them there were (279 (57.9\%) male and 203 (42.1\%) female patients. Diagnosis of ischemic stroke subtype was based on the mechanism of its development according to TOAST criteria (2015). Totally there were 125 patients with CEI (an average age (69.6 \pm 1.4 ) years old), 119 patients - with LAAS (an average age $(65.7 \pm 1.5)$ years old), 116 patients with Stroke of Undetermined Etiology (UDE) (an average age $(60.7 \pm 0.8)$ years old $)$ and 122 patients with LAC $(57.4 \pm 1.6)$ years old).

Patients were included if they presented with verified diagnosis of ischemic stroke based on non-contrast computed tomographic scan (NCCT) or magneto-resonance imaging (MRI). The patients were followed up in acute period after hospitalization on the $1^{\text {st }}, 7^{\text {th }}$ and $14^{\text {th }}$ day of the disease. Exclusion criteria were as follows: (1) the presence of repeated ischemic strokes and impaired consciousness deeper than sopor (according to Glasgow scale less than 9-10 points), (2) chronic heart failure II B - III stages, III or higher functional class by New York Heart Association (NYHA), (3) chronic kidney disease (filtration rate $\leq 60 \mathrm{~mL} / \mathrm{min}$ ).

Two age categories of patients were studied. The first one included 216 patients at the age $45-59$ years old (the first age group). The second one consisted of 266 patients at the age 60-74 years old (the second age group). All the patients were performed general clinical and clinical neurological examination (with determination of the neurological deficit degree according to the National Institutes of Health Stroke Scale (NIHSS) (Odderson I. R., 1999). Based on NIHSS all strokes were divided into: minor (score 1-4) - 138 (28.6\%), moderate (score 5-15) - $234(48.5 \%)$, moderatel severe (score 15-20) - 93 (19.3\%) and severe stroke (score $21-42)-17(3.5 \%)$ patients. The distribution of ischemic 
strokes subtypes according to severity of neurological deficit is represented in Table 1.

All patients underwent either CT scan (Astelon 4, Toshiba) or MRI (Simens, MagnetomAvanto, $1.5 \mathrm{TI}$ ) in order to confirm the diagnosis of stroke and determine infarct's localization and volume. According to the results all the patients were divided into 3 groups: small infarct (up to $\left.10 \mathrm{sm}^{3}\right)-161$ (33.4\%), medium infarct $\left(10-100 \mathrm{sm}^{3}\right)-235(48.8 \%)$, large infarct $\left(>100 \mathrm{sm}^{3}\right)-86(17.4 \%)$ patients.

Early neurological deterioration (END) was observed in $15.2 \%$ of patients with CEI (mainly due to the hemorrhagic transformation), in $22.7 \%$ of patients with LAAS (due to infarct zone formation, cerebral edema and recurrent cerebro-vascular events), in $11(9.6 \%)$ patients with UDE and $10(8.2 \%)$ patients with LAC.

Ultrasound scanning of extra cranial and intracranial vessels by means of Philips Human Development Index $(\mathrm{HDI})$ and Echo Doppler cardiography by means of «Biomedica» (Japan) were performed. The type of left ventricle (LV) geometry was determined in accordance with the recommendations of the European Society of Hypertension (2007).

Systemic inflammatory response was evaluated according to the level of pro-inflammatory interleukins (IL-1 $1 \beta, \mathrm{IL}-2$, IL-6, IL-8, C-reactive protein (CRP), tumor necrosis factor (TNF-a)) and anti-inflammatory interleukin IL-10 in serum by means of enzyme-linked immune sorbent assay (ELISA) method («Vector-Best», Russia). The control group (CG) consisted of 42 people, representative by age and sex in relation to the patients with brain infarction: 23 male and 19 female at the age of 45 up to 71 years old. The average age of patients in CG was $(60.7 \pm 2.1)$ years. Statistical analysis of the results was made by means of IBM SPSS Statistics using Wilcoxon-Mann-Whitney U-criterion (for independent samples), Wilcoxon t-test (for dependent samples) and factor of pair linear correlation ( $r$ ) by Spearman.

\section{Results and Discussion}

Analysis of cytokine status in patients with ischemic stroke subtypes showed the growth of inflammatory interleukins' level at LAAS, which was probably due to the age and degree of neurological deficit in patients of this cohort (Table 2).
It could be also due to the fact that chronic systemic inflammatory conditions, such as atherosclerosis, diabetes and obesity are associated with increased risk of stroke, which suggests that systemic inflammation may contribute to the development of stroke in humans. The level of IL-2, IL-6 and CRP among these patients was significantly higher compared with ischemic stroke other subtypes.

The level of IL-1 $\beta$, IL-2, IL-6, IL-8 at UDE stroke was significantly lower compared to other ischemic stroke subtypes. The relationship between the concentration of IL-1 $\beta$ and IL- 6 with the severity of ischemic stroke subtypes was established. At LAAS the relationship between stroke severity and concentration of IL- $1 \beta$ was $(r=0.63, p=0.005)$, with IL-6 $-(r=0.71, p=0.002)$; at CEI $-(r=0.58, p=0.006)$ and $(r=0,63, p=0.003)$; at UDE stroke $-(r=0.53, p=0.005)$ and $(r=0.59, p=0.009)$, respectively. At LAC strong correlation was found only with IL-1 $(r=0.69, p=0.002)$. The level of anti-inflammatory cytokine IL-10 at LAAS was significantly lower compared to UDE and LAC. Probably the high level of IL-10 plays a protective role in inflammation limiting at LAC and UDE. Despite the lack of correlation between the level of IL-6, TNF-á and severity of LAC, the study proved that its high level contributes to END. At the same time, a protective effect of IL-10 in the functional prognosis at LAC and its association with END was found. There was a significant moderate correlation between the level of IL-10 and END at LAC, which coincided with the results of other studies, that established the increased infarct's volume on $\mathrm{MRI}$ and worsening of neurological symptoms in patients with subcortical and LAC strokes at lower levels of IL-10.

The level of TNF-á was significantly higher in patients with CEI compared to LAC, but not significantly different from the values of patients with LAAS and UDE. There was a significant difference in the levels of TNF-á in patients with LAC compared with patients with LAAS and UDE. The level of CRP at LAC was significantly lower compared with patients with other ischemic stroke subtypes. The level of CRP increased greatly at LAAS. It was established that small LAAS stroke (up to $10 \mathrm{~cm}^{3}$ ) was associated with significantly higher level of CRP $(p<0.05)$ compared with LAC (despite the almost identical stroke volumes): $(27.61 \pm 0.52) \mathrm{mg} / \mathrm{l}$. These data indicate less impact of CRP on the pathogen-

Table 2. Cytokine status at ischemic stroke subtypes on the $1^{\text {st }}$ and $7^{\text {th }}$ day $(M \pm m)$

\begin{tabular}{|c|c|c|c|c|c|c|}
\hline \multirow[t]{2}{*}{ Index } & \multirow[t]{2}{*}{ Control group } & \multirow[t]{2}{*}{ Day } & \multicolumn{4}{|c|}{ Ischemic stroke subtypes } \\
\hline & & & UDE, $(n=82)$ & LAAS $(n=61)$ & CEI $(n=72)$ & $\operatorname{LAC}(n=59)$ \\
\hline 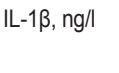 & $2.31 \pm 0.40$ & 1-rst & $14.62 \pm 0.52^{*}$ & $20.90 \pm 0.97$ & $17.64 \pm 0.45$ & $19.02 \pm 0.54$ \\
\hline \multirow[t]{2}{*}{ IL-2, ng/l } & $2.84 \pm 0.22$ & 1- rst & $10.81 \pm 0.53^{*}$ & $19.22 \pm 0.81^{*}$ & $16.17 \pm 0.73$ & $14.92 \pm 0.75$ \\
\hline & & 7- th & $8.95 \pm 0.68^{*}$ & $\underline{17.61 \pm 0.75}$ & $16.07 \pm 0.65$ & $\underline{14.92 \pm 0.75}$ \\
\hline IL-6, ng/l & $2.75 \pm 0.30$ & 1- rst & $45.32 \pm 1.03^{*}$ & $103.24 \pm 2.88^{*}$ & $75.87 \pm 1.70^{*}$ & $64.00 \pm 1.15^{*}$ \\
\hline \multirow[t]{2}{*}{ IL-8, ng/l } & $3.12 \pm 0.41$ & 1- rst & $13.15 \pm 0.67^{*}$ & $48.10 \pm 1.29$ & $45.54 \pm 0.83$ & $30.72 \pm 0.96^{*}$ \\
\hline & & 7- th & $13.15 \pm 1.67^{*}$ & $43.07 \pm 5.11$ & $41.65 \pm 4.29$ & $\underline{21.34 \pm 1.83^{*}}$ \\
\hline \multirow[t]{2}{*}{ IL-10, ng/l } & $5.91 \pm 0.20$ & 1- rst & $6.33 \pm 0.20$ & $5.70 \pm 0.15^{\star}$ & $5.91 \pm 0.18$ & $6.24 \pm 0.22$ \\
\hline & & 7- th & $6.05 \pm 0.15$ & $5.42 \pm 0.12$ & $5.54 \pm 0.18$ & $6.08 \pm 0.24$ \\
\hline \multirow[t]{2}{*}{ CRP, mg/l } & $1.45 \pm 0.02$ & 1- rst & $18.80 \pm 0.63^{*}$ & $43.54 \pm 1.45^{*}$ & $38.43 \pm 0.92$ & $12.33 \pm 0.74^{*}$ \\
\hline & & 7-th & $\underline{14.17 \pm 0.59^{*}}$ & $\underline{37.18 \pm 1.26}$ & $35.49 \pm 1.32$ & $\underline{10.42 \pm 0.68^{*}}$ \\
\hline TNF-á, ng/l & & 7-th & $\underline{22.14 \pm 1.13}$ & $23.67 \pm 1.58$ & $26.95 \pm 1.46^{*}$ & $\underline{20.55 \pm 1.37}$ \\
\hline
\end{tabular}

*: reliable performance in relation to the values of patients with other stroke subtypes $(p<0.05)$; the underlined figures are significantly different compared with those on the $1^{\text {st }}$ day $(p<0.05)$. 
esis of LAC compared with other cytokines, including IL-6 and IL-10.

Clinical-immune biochemical comparing study of cytokines variable level on the $7^{\text {th }}$ day of stroke was performed. As it is considered that inflammatory responses play an important role in infarct formation, it can take several days. Therefore, it was important to assess not only the initial level of pro-inflammatory mediators that may be caused by genetic activity of the immune system, but also their further changes within 7 days when inflammatory reactions reach the maximum of their development.

Significant decrease $(p<0.05)$ of IL-1 $1 \beta, I L-2, I L-6, I L-8$, TNF-á levels and unremarkable decrease of IL-10 was established compared to the first day. The level of CRP did not differ significantly in relation to baseline values. Increased level of CRP and decreased level of anti-inflammatory cytokine IL-10 during the acute period of ischemic stroke proved activation of inflammatory response acute phase on the background of anti-inflammatory cytokine regulation factors suppression.

Significant decrease $(p<0.05)$ of all studied inflammatory parameters in two age groups on the $7^{\text {th }}$ day of ischemic stroke was established. There was no significant correlation between the concentration of IL-1 $\beta$, IL-2, TNF-á and patients' age. The level of IL-6, IL-8 and CRP was significantly $(p<0.05)$ higher in elderly patients compared with middle-aged patients. On the $7^{\text {th }}$ day of stroke the level of IL-10 in middle-aged patients was significantly higher compared with elderly patients. This indicates strong imbalance between pro-inflammatory and anti-inflammatory cytokines during the first days of ischemic stroke acute period in elderly patients that can lead to increased inflammation in infarct zone and damage of brain tissue.

The cytokine status correlated with the degree of ischemic stroke severity. On the $7^{\text {th }}$ day compared to the first one significantly reduced level of IL-1 $\beta$, IL-2, IL-6, IL-8, CRP, TNF-á $(p<0.05)$ was observed in patients with minor ischemic stroke, that may indicate a favorable disease course. At moderate ischemic stroke significantly decreased the level of IL-1 $1 \beta$ and TNF-á. At moderate/severe ischemic stroke inflammatory changes in the infarct zone continued to abstain. The average level of cytokine IL-10 in patients with minor ischemic stroke significantly did not differ from that one in control group. At severe ischemic stroke the level of IL-10 remained significantly $(p<0.01)$ lower compared with that one at minor stroke and in control group. There was a significant decrease of IL-1 $\beta$, IL-2, IL-6 and IL-8 in patients with minor stroke $(p<0.05)$. At large strokes, there was no significant positive dynamics in level of pro-inflammatory cytokines.

Significant reduction of the level of IL-1 $\beta, I L-2, I L-6$, IL-8, CRP and TNF-á was found in patients without END. The concentration of IL-10 on the $7^{\text {th }}$ day of stroke was significantly higher in patients without END. The contribution of cytokines, including IL- 6 and TNF- $\alpha$, into END at ischemic stroke can be realized by improving the adhesion of white blood cells, causing microvascular obstruction, increasing infarction and deepening brain tissue damage. In addition, during the acute period of ischemic stroke progression of secondary damage zone with subcritical perfusion (ischemic penumbra), high risk of cerebral infarction on the background of insufficient production of protective factors, including the level of pro-inflammatory cytokine IL-10, is possible. This is one of the main factors that lead to the activation of inflammatory reaction and creates background for early negative dynamics in neurological status [7].

Depending on ischemic stroke subtype, it has been found that the concentration of IL- $1 \beta$ and IL- 8 was significantly decreased only at LAC. IL-2 significantly reduced in dynamics at LAC and LAAS. Especially high level of IL-2 was observed at CEI, accompanied by hemorrhagic transformation. We found unremarkable decreasing of IL-6 level in patients with CEI and UDE. The study revealed significantly lower concentrations of IL-6 in dynamics on the $7^{\text {th }}$ day of stroke at UDE. However, the level of IL-6 was significantly decreased only in patients with minor or medium infarction. There were no significant differences between the content of IL- 6 on the $1^{\text {st }}$ and $7^{\text {th }}$ day at large volume UDE. Significantly lower rates of IL-6 were observed at LAC. The level of IL-10 on the $7^{\text {th }}$ day of CEI and UDE declined and was significantly lower compared with the patients of control group. The variable level of IL-10 at LAC and UDE did not significantly change and did not differ from the values of control group patients. Our study reaffirms the idea of an imbalance between pro-inflammatory and anti-inflammatory cytokines, which may occur in some ischemic stroke subtypes. The content of TNF-á significantly reduced at LAC and UDE. The level of CRP at all ischemic stroke subtypes remained significantly higher than in patients of control group.

Significant decline of the level of CRP was observed at UDE, LAAS and LAC. The concentration of CRP was significantly higher at LAAS and CEI compared with LAC and UDE. This fact points to the important role of inflammation in the acute period of CEI and LAAS. The severity of state on the $14^{\text {th }}$ day of stroke correlated with the concentration of CRP on the $1^{\text {st }}$ day at LAAS $(r=0.73, p=0.003)$ and CEI $(r=0.71, p=0.002)$. We also found the correlation between the severity of LAAS on the $7^{\text {th }}$ day and the level of CRP on the $1^{\text {st }}$ day $(r=0.58, p=0.011)$. The result of studies showed that the high content of CRP may be a marker of unfavorable course of acute period at LAAS and CEI. CRP is one of the important factors that play role in all stages of atherosclerosis with atherosclerotic plaque formation in occurrence and progression of acute ischemic stroke [8].

The literature provides various data on the prognostic value of CRP for ischemic stroke subtypes. It has been shown that elevated levels of high sensitivity (hs) CRP associated significantly with all stroke subtypes classified according to Trial of ORG 10172 in Acute Stroke Treatment classification except for lacunar stroke and stroke of other determined etiology. Hs-CRP is an independent prognostic factor of poor outcome within 3 months. Although other studies have shown that hs-CRP levels predict the risk of recurrent strokes and other vascular events did not predict the response to dual antiplatelets [9] and can be independent predictor of poor prognosis in younger patients [10].

In the acute period of LAAS we found correlation between the degree of atherosclerotic lesion of cerebral magistral arteries (CMA) and the severity of inflammatory changes, including the content of CRP. The level of CRP at LAAS correlated with artery stenosis degree $r=0.33$ $(p<0.05)$, the presence of unstable atherosclerotic plaque $r=0.6(p<0.05)$. In patients with one atherosclerotic plaque the level of CRP on the $1^{\text {st }}$ day of stroke was significantly 
Table 3. Cytokine status on the $1^{\text {st }}$ day of undetermined stroke according to the type of left ventricular remodeling ( $\left.M \pm m\right)$

\begin{tabular}{|c|c|c|c|c|}
\hline \multirow[t]{2}{*}{ Parameter } & \multicolumn{4}{|l|}{ Type of heart remodeling } \\
\hline & $\begin{array}{l}\text { Normal left ventricular geometry, } \\
(n=14)\end{array}$ & $\begin{array}{l}\text { Concentric hypertrophy, } \\
(n=25)\end{array}$ & $\begin{array}{l}\text { Eccentric hypertrophy, } \\
(n=23)\end{array}$ & $\begin{array}{l}\text { Concentric remodeling, } \\
(n=20)\end{array}$ \\
\hline IL-2, pg\| & $8,56 \pm 0,68$ & $9,89 \pm 0,70$ & $9,94 \pm 0,54$ & $9,06 \pm 0,82$ \\
\hline IL-6, pg\| & $37,25 \pm 2,31$ & $46,18 \pm 2,44^{*}$ & $41,16 \pm 2,00$ & $38,12 \pm 1,85$ \\
\hline IL-8, pg| & $12,95 \pm 0,90$ & $14,08 \pm 1,13$ & $13,65 \pm 1,86$ & $12,22 \pm 1,05$ \\
\hline CRP, mg/l & $14,65 \pm 0,34$ & $19,22 \pm 0,41^{*}$ & $15,33 \pm 0,36$ & $15,08 \pm 0,42$ \\
\hline TNF-á, pgll & $24,39 \pm 0,78$ & $26,45 \pm 1,21$ & $25,88 \pm 1,17$ & $24,66 \pm 0,85$ \\
\hline
\end{tabular}

*: reliable performance in relation to other types of remodeling $(p<0.05)$.

lower than in patients with multiple atherosclerotic plaques: $(18.06 \pm 1.20) \mathrm{mg} / \mathrm{l}(22.71 \pm 1.52) \mathrm{mg} / \mathrm{l}$, respectively.

An important criterion for severity of atherosclerotic process is the thickness of complex intima media (CIM). We made the analysis of the correlation between the thickness of CIM and the level of CRP. On the $1^{\text {st }}$ day of ischemic stroke we found a weak correlation between these indexes $(r=0.24, p=0.040)$. On the $7^{\text {th }}$ day of stroke we found marked strengthening of correlation $(r=0.38$, $p=0.025$ ). The highest correlation between the thickness of CIM and level of CRP was observed on the $7^{\text {th }}$ day of LAAS $(r=0.42, p=0.015)$.

In the acute period of ischemic stroke we found correlation between the level of CRP and the presence of unstable atherosclerotic plaques. In patients with stable atherosclerotic plaques the level of CRP was $(40.12 \pm 0.94)$, with unstable - $(46.35 \pm 0.89) \mathrm{mg} / \mathrm{l}$. This fact indicates the role of CRP in formation of unstable atherosclerotic plaques.

The level of pro-inflammatory cytokines IL-1 $\beta$, IL- 6 and CRP in acute period of UDE correlated with left ventricle geometry. The highest content of these cytokines was observed in patients with concentric left ventricular hypertrophy (Table 3).

Significant correlations between left-ventricular myocardial mass index (MMI) and the level of IL-1 $\beta$ on the $1^{\text {st }}$ and $7^{\text {th }}$ day of UDE $((r=0.30, p=0.025)$ and $(r=0.40, p=0.012)$ respectively) and the level of IL- 6 on $1^{\text {st }}$ day $-(r=0.50$, $p=0.020$ ). The results of study indicate that pathological cardiac remodeling (particularly concentric hypertrophy) as a result of hypertension may occur as a result of increased synthesis of IL-6 due to pathological changes in myocardium. Although, in general, the levels of IL-10 in patients with UDE were not significantly different from the values of patients in control group, we found correlation of this type of cytokine with the type of left ventricular remodeling. On the $1^{\text {st }}$ day of UDE the content of IL-10 was significantly lower in patients with concentric left ventricular hypertrophy compared with patients with normal geometry and concentric left ventricular remodeling $(p<0.05)$. We found correlation between the level of IL-10 on the $1^{\text {st }}$ day of ischemic stroke with left ventricular MMI $(r=-0.43, p=0.009)$.

\section{Conclusions}

1. The level of pro-inflammatory cytokines increases in the acute period of ischemic stroke subtypes. These changes are the most remarkable at LAAS and CEI.

2. At LAAS, the level of inflammatory mediators cor- related with the degree of artery stenosis and presence of unstable atherosclerotic plaques. We found a direct relationship between the severity of LAAS and CEI on the $14^{\text {th }}$ day of stroke and the level of CRP on the $1^{\text {st }}$ day of stroke (at LAAS - $(r=0.73, p=0.003)$, at CEI $-(r=0.71, p=0.002)$. The results of the study revealed the prognostic value of the level of CRP on the course of acute period of ischemic stroke subtypes.

3. We found the dependence between cardiac morphometric parameters (according to the results of echo Doppler cardiography) and the level of pro-inflammatory interleukins in acute period of UDE. We established the strong correlation between the content of IL-1 $1 \beta, \mathrm{IL}-6$ and left ventricular myocardial mass index at UDE.

The perspectives of further scientific research include design of new methods for cytokine status correction depending on the brain infarction subtype.

\section{References}

[1] Kim, J., Kawabori, M., \& Yenari, M. (2014) Innate inflammatory responses in stroke: mechanisms and potential therapeutic targets. Current Medicinal Chemistry, 21(18), 2076-97.

[2] Kawabori, M., \& Yenari, M. (2015) Inflammatory responses in brain ischemia. Current Medicinal Chemistry, 22(10), 1258-77. doi: 10.2174 10929867322666150209154036.

[3] Anrather, J., \& ladecola, C. (2016) Inflammation and Stroke: An Overview. Neurotherapeutics, 13(4), 661-670. doi: 10.1007/s13311016-0483-x.

[4] Tuttolomond, A., Di Raimond, D., Pecoraro, R., Arnao, V., Pinto, A., \& Licata, G. (2012) Inflammation in Ischemic Stroke Subtypes. Current Pharmaceutical Design, 18, 4289-4310.

[5] Licata, G., Tuttolomondo, A., Di Raimondo, D., Corrao, S., Di Sciacca, R., \& Pinto, A. (2009) Immuno-inflammatory activation in acute cardio-embolic strokes in comparison with other subtypes of ischaemic stroke. Thrombosis and Haemostasis, 101(5), 929-937. doi: 10.1160/ th08-06-0375.

[6] Boehme, A. K., McClure, L. A., Zhang, Y., Luna, J. M., Del Brutto, O. H., Benavente, O. R., \& Elkind, M. S. (2016) Inflammatory Markers and Outcomes After Lacunar Stroke: Levels of Inflammatory Markers in Treatment of Stroke Study. Stroke, 47(3), 659-67. doi: 10.1161/ STROKEAHA.115.012166.

[7] Welsh, P., Barber, M., Langhorne, P., Rumley, A., Lowe, J., \& Stott, D. (2009) Associations of inflammatory and haemostatic biomarkers with poor outcome in acute ischaemic stroke. Cerebrovascular Diseases, 27(3), 247-53. doi: 10.1159/000196823.

[8] Shrivastava, A., Singh, H., Raizada, A., \& Singh, S. (2015) C-reactive protein, inflammation and coronary heart disease. The Egyptian Heart Journal., 2015, 67(2), 89-97. doi: 10.1016/j.ehj.2014.11.005.

[9] Elkind, M., Luna, J., \& McClure, L. (2014) C-reactive protein as a prognostic marker after lacunar stroke: levels of inflammatory markers in the treatment of stroke study. Stroke, 45(3), 707-16. doi: 10.1161/ STROKEAHA.113.004562.

[10] Qiu, R., Gao, Y., Hou, D., Yu, C., Wang, W., Liu, S., et al. (2016) Association between hs-CRP Levels and the Outcomes of Patients with Small-Artery Occlusion. Frontiers in Aging Neuroscience, 9(8), 191. doi: 10.3389/fnagi.2016.00191. 
Information about authors:

Shkrobot S. I., MD, PhD, DSci, Professor, Department of Neurology,

Psychiatry, Narcology and Medical Psychology, I. Horbachevskyy

Ternopil State Medical University, Ukraine.

Sokhor N. R., MD, PhD, DSci, Associate Professor, Department

of Neurology, Psychiatry, Narcology and Medical Psychology,

I. Horbachevskyy Ternopil State Medical University, Ukraine.

Milevska-Vovchuk L. S., MD, PhD, Associate Professor, Department

of Neurology, Psychiatry, Narcology and Medical Psychology,

I. Horbachevskyy Ternopil State Medical University, Ukraine. Shkrobot L. V., MD, PhD, DSci, Chief Doctor, Ternopil Regional Oncology Health Center, Ukraine.

\section{Відомості про авторів:}

Шкробот С. І., А-р меА. наук, професор,

зав. каф. неврології, психіатрії, наркології та медичної психології, АВНЗ “Тернопімьський Аержавний меАичний університет імені І. Я. Горбачевського МОЗ України".

Сохор Н. Р., А-р меА. наук, Аоцент каф. неврології, психіатрії, наркології та медичної психології, АВНЗ "Тернопільський Аержавний медичний університет імені І. Я. Горбачевського МО3 Україним.

Мілевська-Вовчук ^. С., канА. меА. наук, Аоцент каф. неврології, психіатрії, наркології та медичної психології,

АВНЗ «Тернопільський Аержавний меАичний університет імені І. Я. Горбачевського М0З України".

Шкробот ^. В., А-р меА. наук, головний лікар Тернопільського обласного онкологічного диспансера, Україна.

\section{Сведения об авторах:}

Шкробот С. И., А-р меА. наук, профессор, зав. каф. неврологии, психиатрии, наркологии и медицинской психологии,

ГВУЗ "Тернопольский госуАарственный меАицинский

университет имени И. Я. Горбачевского МОЗ Украины”.

Сохор Н. Р., А-р меА. наук, Аоцент каф. неврологии, психиатрии, наркологии и меАицинской психологии, ГВУЗ «Тернопольский государственный меАицинский университет имени И. Я. Горбачевского МОЗ Украины".

Милевская-Вовчук $\Lambda$. С., канА. меА. наук, Аоцент каф. неврологии, психиатрии, наркологии и медицинской психологии, ГВУЗ «Тернопольский госуАарственный меАицинский университет имени И. Я. Горбачевского МОЗ Украины».

Шкробот ^. В., А-р меА. наук, главный врач Тернопольского областного онкологического Аиспансера, Украина.

Конфлікт інтересів: віАсутній.

Conflicts of Interest: authors have no conflict of interest to declare.

Надійшло Ао реАакції / Received: 13.02.2017

Після Аоопрацювання / Revised: 28.02.2017

Прийнято Ао Аруку / Accepted: 01.03.2017 